\title{
ANALISIS PENGELOLAAN BENDA CAGAR BUDAYA SEBAGAI KEKAYAAN DIKUASAI NEGARA DI BALAI PELESTARIAN CAGAR BUDAYA D.I YOGYAKARTA
}

Muhammad Naufal Faraj El Gibarj ${ }^{1}$ dan Pratin ${ }^{2}$

Politeknik Keuangan Negara STAN

E-mail : pratinstanppk@pknstan.ac.id

\author{
INFORMASI ARTIKEL \\ Diterima Pertama \\ [ 28 Mei 2021] \\ Dinyatakan Diterima \\ [24 Juli 2021]
}

Kata Kunci:

Pengelolaan, BMN, Cagar Budaya
ABSTRAK

This study is a management review of cultural heritage as Government's Assets (Bahasa Indonesia: Barang Milik Negara) managed by Cultural Heritage Preservation Center of Special Region Yogyakarta (BPCB DIY). This study aims to find out the management of cultural heritage by BPCB DIY based on the applicable laws and regulations. This research is a qualitative study through interviews and literature study. Interview were conducted with BPCB DIY. Literature studies are carried out on related laws and regulations, official websites, financial reports publication of related agencies and companies, and publication of cultural heritage statistics. The review result show that BPCB DIY has carried out its duties and function as cultural heritage preserver, but there are technical issues about administration and maintaining cost.

Penelitian ini merupakan tinjauan pengelolaan Barang Milik Negara (BMN) berupa cagar budaya yang dikelola Balai Pelestarian Cagar Budaya Daerah Istimewa Yogyakarta (BPCB DIY) dan bertujuan untuk mengetahui pengelolaan BMN cagar budaya oleh BPCB DIY berdasarkan peraturan perundang-undangan yang berlaku. Penelitian ini merupakan studi kualitatif dengan pengumpulan data melalui wawancara dan studi pustaka. Wawancara dilakukan dengan narasumber kepala bagian umum dan kepala bagain publikasi dan dokumentasi BPCB DIY. Studi pustaka dilakukan terhadap peraturan perundang-undangan terkait, laman-laman resmi, publikasi laporan keuangan intansi dan perusahan terkait, dan publikasi statistik cagar budaya. Hasil tinjauan menunjukkan BPCB DIY telah melaksanakan tugas dan fungsi sebagai pelestari cagar budaya, namun terdapat masalah teknis terhadap penatausahaan cagar budaya sebagai BMN dan pembebanan pemeliharaan atas cagar budaya yang tidak dimiliki dan dikuasai pemerintah. 


\section{PENDAHULUAN}

\subsection{Latar Belakang}

Indonesia merupakan negara dengan sejarah yang panjang. Berbagai kebudayaan ditinggalkan oleh para pelaku sejarah untuk membentuk Indonesia saat ini. Bagi Indonesia sekarang, kebudayaan-kebudayaan tersebut merupakan aset tak terhitung nilainya, baik yang berwujud maupun tidak. Pemerintah pusat melalui Kementerian Pendidikan dan Kebudayaan, bekerja sama dengan Kementerian Keuangan, hadir sebagai regulator, pelestari, dan pengelola peninggalan-peninggalan tersebut.

Kekayaan dikuasai negara merupakan kekayaan negara yang diatur regulasi pengelolaannya oleh negara, namun tidak dimiliki negara sehingga tidak termasuk dalam mekanisme APBN. Regulasi tersebut disusun dan dilaksanakan oleh kementerian atau lembaga negara teknis terkait yang berkoordinasi dengan Kementerian Keuangan dan BAPPENAS. Pengelolaan dan pemanfaatan kekayaan dikuasai negara harus sejalan dengan amanat UUD 1945 Pasal 33 Ayat 3 tentang penggunaan bumi, air, dan kekayaan alam yang terkandung di dalamnya untuk sebesarbesarnya kemakmuran rakyat. Meskipun kekayaan ini belum memiliki potensi fiskal, pemerintah terus melakukan penelitian dan pengembangan terkait mekanisme pengelolaannya, terutama kekayaan sumber daya alam (SDA), yang saat ini dituangkan dalam RUU Pengelolaan Kekayaan Negara.

Sesuai amanat PP Nomor 27 Tahun 2014 tentang Pengelolaan BMN, pengelolaan kekayaan negara tertentu diatur dalam Peraturan Menteri Keuangan Nomor 234/PMK.01/2015 tentang Organisasi dan Tata Kerja Kementerian Keuangan, yang salah satu ruang lingkupnya adalah cagar budaya. Benda Cagar Budaya (BCB) sebagai salah satu kekayaan dikuasai negara tentu harus memberikan manfaat bagi rakyat sesuai relevansinya, seperti sebagai media edukasi dan pariwisata sejarah Indonesia untuk cagar budaya jenis koleksi museum, koleksi luar ruangan, atau situs. Sedangkan cagar budaya berupa bangunan bisa dimanfaatkan sebagai fasilitas publik seperti sekolah, rumah sakit, tempat ibadah, atau bahkan kantor pemerintah yang tentu pemeliharaannya menggunakan mekanisme khusus.

Jumlah cagar budaya Indonesia pada tahun 2019 mencapai 2.907 terdaftar, dan Daerah Istimewa Yogyakarta adalah salah satu provinsi dengan jumlah cagar budaya terbanyak, sebanyak 707 buah atau $24,3 \%$. Sudah sepatutnya pemerintah, dalam hal ini melalui Kementerian Pendidikan dan Kebudayaan yang berkoordinasi dengan Kementerian Keuangan, mengelola kekayaan tersebut dengan baik, efisien, dan bermanfaat, baik dalam segi pencarian, registrasi, pelestarian, dan pemanfaatan, serta penatausahaan sebagai BMN.

Meskipun tidak tejadi kasus yang signifikan terhadap pengelolaan cagar budaya, kerusakankerusakan cagar budaya, seperti kasus kerusakan cagar budaya Masjid Besar Pakualam dan Eks Hotel Tugu Yogyakarta yang rusak karena tak terawat maupun kasus rusaknya bangunan SMA Negeri 17 Yogyakarta akibat oknum-oknum tidak bertanggung jawab, menunjukkan bahwa masih minimnya pengawasan bahkan pemeliharaan yang dilakukan oleh BPCB DIY meski beberapa kasus sudah ditindaklanjuti.

Selain itu, mengingat besarnya kontribusi Daerah Istimewa Yogyakarta terhadap kuantitas dan kualitas cagar budaya secara nasional serta perlunya tinjauan pengelolaan cagar budaya di BPCB DIY, maka sebagai obyek penelitian adalah pengelolaan cagar budaya di provinsi tersebut.

\subsection{Rumusan Masalah}

Rumusan masalahnya adalah bagaimana pengelolaan BMN berupa cagar budaya di BPCB DIY?

\subsection{Tujuan Penulisan}

Tujuan penulisannya adalah menganalisis pengelolaan BMN berupa cagar budaya di BPCB DIY.

\section{KERANGKA TEORI}

\subsection{Kekayaan Dimiliki Negara dan Kekayaan Dikuasai Negara}

Dalam menjalankan tugasnya, pemerintah pusat atau negara dapat memiliki barang sebagai suatu badan hukum (Pasal 23C UUD 1945) atau menjalankan tugasnya untuk memiliki barang tersebut. Kekayaan negara merupakan bagian dari keuangan negara yang terdiri dari uang, surat berharga, piutang, barang, hakhak lain bernilai uang, dan kekayaan dipisahkan yang ditanamkan di BUMN (UU Nomor 17 Tahun 2003). Sesuai PP Nomor 28 Tahun 2020, perubahan atas PP Nomor 27 Tahun 2014, Barang Milik Negara (BMN) adalah barang yang diperoleh dari Anggaran Pendapatan dan Belanja Negara (APBN) atau perolehan sah lainnya.

Selain memiliki kekayaan, salah satu tugas pemerintah adalah menjadi pembuat dan pengawas kebijakan kekayaan negara. Kekayaan negara (baik yang dimiliki negara atau masyarakat) merupakan kekayaan yang dikuasai negara. Dikuasai berarti pengelolaannya harus mengikuti aturan negara yang berlaku, atau negara berperan sebagai regulator. 
Sedangkan pada kekayaan yang dimiliki negara, selain sebagai regulator, negara berperan sebagai eksekutor.

\subsection{Benda Cagar Budaya}

Kementerian Keuangan sebagai pengelola fiskal, berperan untuk mengelola BMN yang digunakan oleh seluruh Satuan Kerja (Satker) kementerian dan lembaga, termasuk kekayaan dimiliki negara lain-lain atau kekayaan negara lain-lain. Kekayaan negara lainlain yang dimaksud terdiri dari aset eks BPPN dan likuidasi bank; nasionalisasi aset asing dan tionghoa; cagar budaya dan benda berharga muatan kapal tenggelam; bekas kepabeanan; rampasan negara; dan hak bumi, air, langit, dan kekayaan intelektual (PMK Nomor 234/PMK.01/2015).

Benda Cagar Budaya (BCB), sebagai salah satu dari BMN dalam kekayaan negara lain-lain, adalah benda alam dan/atau buatan manusia, bergerak atau tidak bergerak, kesatuan atau kelompok, atau bagianbagiannya, atau sisa-sisanya yang memiliki hubungan erat dengan kebudayaan dan sejarah perkembangan manusia. Sedangkan secara umum, cagar budaya adalah warisan budaya bersifat kebendaan berupa benda, bangunan, struktur, situs, dan kawasan cagar budaya yang berada di darat atau air dan perlu dilestarikan keberadaannya karena bernilai penting bagi sejarah, ilmu pengetahuan, pendidikan, agama, dan/atau kebudayaan melalui proses penetapan (UU Nomor 11 Tahun 2010).

Selain benda, menurut UU Nomor 11 Tahun 2010, cagar budaya memiliki empat jenis peninggalan lainnya berdasarkan sifat kebudayaannya, yakni bangunan, struktur, situs, dan kawasan cagar budaya. Bangunan Cagar Budaya merupakan susunan binaan yang terbuat dari benda alam atau buatan manusia untuk memenuhi kebutuhan ruang berdinding dan/atau tanpa dinding, dan beratap. Struktur Cagar Budaya merupakan susunan binaan yang terbuat dari benda alam atau buatan manusia untuk memenuhi kebutuhan ruang kegiatan yang menyatu dengan alam, sarana, dan prasarana untuk menampung kebutuhan manusia. Situs Cagar Budaya merupakan lokasi yang berada di darat dan/atau di air yang mengandung Benda Cagar Budaya, Bangunan Cagar Budaya, dan/atau Struktur Cagar Budaya sebagai hasil kegiatan manusia atau bukti kejadian masa lalu. Sedangkan Kawasan Cagar Budaya marupakan satuan ruang geografis yang memiliki dua Situs Cagar Budaya atau lebih yang letaknya berdekatan dan/atau memperlihatkan ciri tata ruang yang khas.

Sesuai UU Nomor 11 tahun 2010, cagar budaya dapat dimiliki atau dikuasai oleh setiap Warga Negara Indonesia atau Badan Hukum Indonesia sepanjang sesuai ketentuan peraturan perundang-undangan dan jumlah-jenis cagar budaya teresebut telah dipenuhi oleh negara. Kepemilikan cagar budaya dapat diperoleh melalui pewarisan, hibah, tukar-menukar, hadiah, pembelian, atau putusan pengadilan. Cagar budaya tanpa pemilik dan kepemilikannya tidak dialihkan, secara undang-undang akan menjadi milik negara. Sedangkan cagar budaya yang tidak diketahui kepemilikannya menjadi dalam penguasaan negara. Cagar budaya yang dimiliki oleh negara tidak dapat dialihkan kepemilikannya.

Menurut UU Nomor 11 Tahun 2010 pula, pengelolaan cagar budaya dilakukan dalam beberapa tahap, yakni penemuan dan pencarian, register nasional yang berupa kegiatan pendaftaran; pengkajian; penetapan; pencatatan; pemeringkatan; dan penghapusan, dan tahap pelestarian yang berupa kegiatan pelestarian; pelindungan (penyelamatan, pengamanan, zonasi, pemeliharaan, dan pemugaran); pengembangan (pengembangan, penelitian, revitalisasi, dan adaptasi); dan pemanfaatan.

Pada tahap penemuan dan pencarian, kegiatan penemuan cagar budaya dapat dilakukan oleh setiap orang yang menemukan cagar budaya atau yang diduga cagar budaya dengan melapor kepada pihak yang berwenang di bidang kebudayaan, kepolisian, atau pihak terkait agar dilakukan pengkajian. Sedangkan pencarian dilakukan oleh pemerintah. Tanpa ijin pemerintah, setiap orang dilarang untuk melakukan pencarian cagar budaya, baik berupa penggalian, penyelaman, dan/atau pengangkatan darat atau air.

Pada tahap pendaftaran, setiap orang yang memiliki dan/atau menguasai cagar budaya mendaftarkannya kepada pemerintah kabupaten/kota. Hasil pendaftaran cagar budaya diserahkan kepada tim ahli cagar budaya untuk dikaji kelayakannya sebagai cagar budaya. Penetapan dilakukan oleh bupati/walikota setelah menerima rekomendasi dari tim ahli cagar budaya yang menyatakan layak sebagai cagar budaya. Kemudian tahap pemeringkatan dilakukan oleh pemerintah dan pemerintah daerah berdasarkan tingkat kepentingannya, menjadi peringkat nasional, peringkat provinsi, atau peringkat kabupaten/kota berdasarkan rekomendasi tim ahli. Pada tahap penghapusan, cagar budaya yang tercatat dalam Sistem Register Nasional Cagar Budaya dapat dihapus melalui keputusan menteri atas rekomendasi tim ahli tingkat pemerintah.

Kegiatan pelestarian dilakukan berdasarkan studi kelayakan yang dapat dipertanggungjawabkan dan dilaksanakan oleh tenaga ahli pelestarian. Pengamanan dilakukan oleh pemilik atau yang menguasainya dengan menjaga dan mencegah cagar budaya agar tidak hilang, rusak, hancur, atau musnah. Kegiatan zonasi merupakan penentuan batas-batas keruangan Situs Cagar Budaya dan Kawasan Cagar Budaya. Kemudian kegiatan pemeliharaan dapat 
ANALISIS PENGELOLAAN BENDA CAGAR BUDAYA SEBAGAI KEKAYAAN DIKUASAI NEGARA DI BALAI PELESTARIAN CAGAR BUDAYA D.I

YOGYAKARTA.

Muhammad Naufal Faraj El Gibarj ${ }^{1}$ dan Pratin $^{2}$

berupa perawatan dan penanggulangan kerusakan akibat gangguan alam dan/atau manusia, sedangkan kegiatan perawatan berupa pembersihan, pengawetan, dan perbaikan tanpa merubah keaslian bentuk, tata letak, gaya, bahan, dan/atau teknologi cagar budaya. Kegiatan pemugaran dilakukan pada Bangunan atau Struktur Cagar Budaya yang rusak untuk mengembalikan kondisi fisik dengan cara memperbaiki, memperkuat, dan/atau mengawetkannya melalui pekerjaan rekonstruksi, konsolidasi, rehabilitiasi, dan restorasi. Kegiatan pengembangan dapat diarahkan pada pengembangan ekonomi yang hasilnya digunakan untuk pemeliharaan cagar budaya. Kegiatan revitalisasi berupa pengembangan untuk menumbuhkan kembali nilai-nilai penting cagar budaya dengan penyesuaian fungsi ruang baru yang tidak bertentangan dengan prinsip pelestarian dan nilai budaya masyarakat. Adaptasi merupakan kegiatan pengembangan cagar budaya untuk kegiatan yang lebih sesuai dengan kebutuhan masa kini dengan melakukan perubahan terbatas yang tidak mengakibatkan penurunan nilai pentingnya atau kerusakan pada bagian bernilai penting. Kemudian adaptasi dilakukan berupa menambah fasilitas sesuai kebutuhan dan mengubah susuanan ruang secara terbatas.

Kegiatan pemanfaatan dapat dilakukan oleh setiap orang, pemerintah, dan pemerintah daerah untuk kepentingan agama, sosial, pendidikan, ilmu pengetahuan, teknologi, kebudayaan, dan pariwisata. Pemerintah dan pemerintah daerah bertugas memfasilitasi pemanfaatan dan promosi cagar budaya berupa izin pemanfaatan, dukungan tenaga ahli, pelestarian, dukungan dana, dan/atau pelatihan.

\section{METODE PENELITIAN}

\subsection{Sumber Data}

Sumber data utama karya tulis ini adalah hasil wawancara dengan instansi objek penelitian, yakni BPCB DIY yang dilakukan pada 27 April 2021 di BPCB DIY dengan narasumber kepala bagian umum dan kepala bagian publikasi dan dokumentasi BPCB DIY. Wawancara dengan narasumber juga memberikan data berupa rincian jumlah cagar budaya yang menjadi tanggung jawab BPCB DIY. Peraturan perundanganundangan terkait yang tersedia daring digunakan sebagai acuan tinjauan. Data penunjang lainnya yang digunakan berupa literatur-literatur daring, seperti laman resmi, publikasi laporan keuangan, dan publikasi statistik cagar budaya.

\section{HASIL PENELITIAN}

\subsection{Pengelolaan Benda Cagar Budaya di Balai Pelestarian Cagar Budaya Daerah Istimewa Yogyakarta}

Sesuai tugas dan fungsi BPCB, BPCB DIY melakukan tugas pelestarian cagar budaya berupa pelindungan, pengembangan, dan pemanfaatan cagar budaya di wilayah Daerah Istimewa Yogyakarta. BPCB DIY memfasilitasi pelaporan penemuan cagar budaya atas wewenangnya dalam bidang kebudayaan. BPCB DIY kemudian mengirimkan tim ahli untuk mengkaji kelayakan cagar budaya atau yang diduga cagar budaya. BPCB DIY juga melakukan kegiatan pencarian cagar budaya melalui kelompok jabatan fungsional. BPCB DIY juga meregistrasikan cagar budaya yang telah layak kajian oleh tim ahli melalui Register Nasional Cagar Budaya dan dipublikasikan nasional secara elektronik melalui laman resmi Register Nasional Cagar Budaya. Sistem informasi internal BPCB DIY masih dilakukan pencatatan manual secara offline atau belum terintegrasi, baik internal maupun nasional. Dokumentasi dan publikasi data cagar budaya dilakukan melalui Pokja Dokumentasi dan Publikasi.

Berikut adalah data cagar budaya yang menjadi tanggung jawab BPCB DIY per Maret 2021.

Tabel 4.1 Persebaran Jumlah Cagar Budaya di Wilayah Daerah Istimewa Yogyakarta

\begin{tabular}{|l|c|c|}
\hline Kabupaten/Kota & $\begin{array}{c}\text { Objek } \\
\text { Bergerak }\end{array}$ & $\begin{array}{c}\text { Objek Tidak } \\
\text { Bergerak }\end{array}$ \\
\hline Kota Yogyakarta & 180 & 333 \\
\hline $\begin{array}{l}\text { Kabupaten } \\
\text { Sleman }\end{array}$ & 5160 & 289 \\
\hline $\begin{array}{l}\text { Kabupaten } \\
\text { Bantul }\end{array}$ & 525 & 169 \\
\hline $\begin{array}{l}\text { Kabupaten } \\
\text { Gunungkidul }\end{array}$ & 545 & 173 \\
\hline $\begin{array}{l}\text { Kabupaten } \\
\text { Kulonprogo }\end{array}$ & 188 & 47 \\
\hline \multicolumn{1}{|c|}{ Jumlah } & 6598 & 1011 \\
\hline
\end{tabular}

Sumber: Data primer yang diperoleh dan diolah penulis Tabel 4.2 Persebaran Jumlah Cagar Budaya di Wilayah Daerah Istimewa Yogyakarta Berdasarkan Penetapan Cagar Budaya UU Nomor 5 Tahun 1992

\begin{tabular}{|l|c|c|}
\hline Kabupaten/Kota & SK Menteri & SK Gubernur \\
\hline Kota Yogyakarta & 131 & 51 \\
\hline $\begin{array}{l}\text { Kabupaten } \\
\text { Sleman }\end{array}$ & 10 & 8 \\
\hline $\begin{array}{l}\text { Kabupaten } \\
\text { Bantul }\end{array}$ & 6 & 3 \\
\hline $\begin{array}{l}\text { Kabupaten } \\
\text { Gunungkidul }\end{array}$ & 2 & 5 \\
\hline $\begin{array}{l}\text { Kabupaten } \\
\text { Kulonprogo }\end{array}$ & 149 & 69 \\
\hline \begin{tabular}{l} 
Jumlah \\
\hline
\end{tabular}
\end{tabular}


ANALISIS PENGELOLAAN BENDA CAGAR BUDAYA SEBAGAI KEKAYAAN DIKUASAI NEGARA DI BALAI PELESTARIAN CAGAR BUDAYA D.I

YOGYAKARTA.

Muhammad Naufal Faraj El Gibarj ${ }^{1}$ dan Pratin $^{2}$

Sumber: Data primer yang diperoleh dan diolah penulis

Tabel 4.3 Persebaran Jumlah Cagar Budaya di Wilayah Daerah Istimewa Yogyakarta Berdasarkan Penetapan Cagar Budaya UU Nomor 11 Tahun 2010

\begin{tabular}{|c|c|c|c|c|c|}
\hline & Benda & Bangunan & Struktur & Situs & Kawasan \\
\hline Kota Yogya & & 39 & & & \\
\hline $\begin{array}{l}\text { Kab. } \\
\text { Sleman }\end{array}$ & 44 & 46 & 9 & 5 & \\
\hline Kab.Bantul & 28 & 27 & 23 & 9 & \\
\hline $\begin{array}{l}\text { Kabupaten } \\
\text { Gunung } \\
\text { kidul }\end{array}$ & 44 & 30 & 2 & 12 & \\
\hline $\begin{array}{l}\text { Kab. } \\
\text { Kulonprogo }\end{array}$ & & 43 & 2 & & \\
\hline $\begin{array}{l}\text { SK } \\
\text { Gubernur }\end{array}$ & 3 & 106 & 8 & 15 & 7 \\
\hline SK Menteri & & 5 & & 1 & \\
\hline Jumlah & 119 & 44 & 296 & 42 & 7 \\
\hline
\end{tabular}

Sumber: Data primer yang diperoleh dan diolah penulis

Pelestarian merupakan kegiatan utama BPCB, termasuk BPCB DIY. Berbagai jabatan fungsional yang ada bertugas untuk melakukan pelestarian sesuai bidang masing-masing yakni pemeliharaan, konservasi, penyelamatan, pengamanan, pemugaran, pemetaan, pengembangan, dan pemanfaatan. Seluruh kegiatan pelestarian yang dilakukan menggunakan APBN sebagai pendanaan. Pemanfaatan yang menyumbang Penerimaan Negara Bukan Pajak (PNBP) juga ikut berkontribusi tidak langsung dalam pendanaan pelestarian.

BPCB DIY memfasilitasi pemanfaatan cagar budaya yang dilestarikannya berupa perizinan. Perizinan dapat diajukan langsung ke kantor BPCB DIY maupun melalui surel. Khusus pemanfaatan Candi Prambanan, permohonan ditujukan kepada Direktorat Warisan dan Diplomasi Budaya karena statusnya yang merupakan cagar budaya nasional. Selain itu, candi yang pemanfaatan pariwisatanya tidak dikelola oleh PT Taman, dikelola langsung oleh BPCB DIY, seperti Candi Ijo, Plaosan, Kalasan, Sari, Sambisari, Barong, dan Gebang.

\subsection{Identifikasi dan Analisis Masalah}

Menurut wawancara yang dilakukan peneliti dengan narasumber, peneliti mengidentifikasi beberapa masalah cagar budaya yang dilestarikan oleh BPCP DIY berkaitan dengan statusnya sebagai Barang Milik Negara.

4.2.1. Penatausahaan Cagar Budaya Berstatus Barang Milik Negara pada Sistem Informasi Barang Milik Negara Belum Maksimal
Sesuai wewenang dan pemeringkatan cagar budaya, yakni tingkat kabupaten/kota, provinsi, atau nasional, cagar budaya dicatatkan pada masing-masing sistem informasi pemerintah atau pemerintah daerah. Menurut bagian keuangan BPCB DIY, cagar budaya tingkat nasional yang dilestarikan oleh BPCB DIY telah ditatausahakan dalam sistem informasi Barang Milik Negara, yakni SIMAK BMN dan SIMAN BMN sebagai benda bersejarah. Benda bersejarah yang ditatausahakan, sesuai ketentuan perundangundangan terkait Barang Milik Negara yang belum memiliki nilai atau belum dilakukan penilaian, hanya bernilai Rp1.

Masalah yang timbul adalah kurangnya kemampuan SDM BPCB DIY di bidang penatausahaan BMN atas cagar budaya yang menjadi tanggung jawabnya. Meskipun BPCB DIY tidak menggunakan cagar budaya yang mereka lestarikan sebagai penunjang tugas dan fungsi, melainkan objek dari tugas dan fungsi mereka, BPCB DIY tetap berkewajiban menatausahakan cagar budaya tersebut sebagai satuan kerja pemerintah. BPCB DIY beranggapan cagar budaya dalam wilayah kerja mereka tidak seharusnya diperlakukan dengan mekanisme Barang Milik Negara seperti yang mereka gunakan untuk menunjang tugas dan fungsi.

Jika dibandingkan dengan kekayaan negara lain-lain lainnya, seperti barang gratifikasi di Komisi Pemeberantasan Korupsi (KPK), aset eks kepabeanan di Direktorat Jenderal Kepabeanan dan Cukai, atau barang rampasan negara di pengadilan, mereka semua merupakan objek dari tugas dan fungsi dari masingmasing satuan kerja dan merupakan Barang Milik Negara yang ditatausahakan sesuai mekanisme Barang Milik Negara melalui Sistem Informasi Barang Milik Negara yang disediakan Kementerian Keuangan. Jadi, seharusnya BPCB DIY menatausahakan objek pelestariannya sesuai mekanisme Barang Milik Negara karena merupakan ranah kerja mereka.

Masalah turunan yang timbul adalah masalah teknis di penatausahaan cagar budaya sebagai BMN. Sesuai pernyataan bagian keuangan BPCB DIY, BPCB DIY telah melakukan penatausahaan cagar budaya pada SIMAK BMN dan SIMAN BMN, namun hanya berupa hasil rekap jumlah cagar budaya yang dilestarikan dan menghasilkan output berupa laporan benda bersejarah. Hal tersebut sudah dilakukan dengan baik, namun datadata yang dibutuhkan belum rinci dan memadai, khususnya pada cagar budaya berupa bangunan, situs, dan kawasan, seperti letak, bukti kepemilikan, dan foto masih belum ditambahkan pada sistem informasi.

4.2.2. Pendapatan Atas Pengoperasian Candi Prambanan dan Ratu Boko oleh PT Taman Wisata Candi Borobudur, Prambanan, dan Ratu 
ANALISIS PENGELOLAAN BENDA CAGAR BUDAYA SEBAGAI KEKAYAAN DIKUASAI NEGARA DI BALAI PELESTARIAN CAGAR BUDAYA D.I

YOGYAKARTA.

Muhammad Naufal Faraj El Gibarj ${ }^{1}$ dan Pratin $^{2}$

Boko yang Tidak Disetorkan ke Kas Umum Negara

PT Taman Wisata Candi Borobudur, Prambanan, dan Ratu Boko, atau biasa disingkat PT Taman, merupakan Badan Usaha Milik Negara (BUMN) yang bergerak di pariwisata kebudayaan. $100 \%$ saham PT Taman dimiliki oleh pemerintah. PT Taman berdiri pada tahun 1980 berdasarkan PP Nomor 7 Tahun 1980 dengan nama PT Taman Wisata Candi Borobudur dan Prambanan. Dalam perkembangannya, Candi Ratu Boko menjadi bagian dari PT Taman pada tahun 1994.

Candi Prambanan dan Ratu Boko merupakan Situs Cagar Budaya yang berada di wilayah kerja BPCB DIY, sehingga BPCB DIY berkewajiban untuk melakukan kegiatan pelestarian kepada dua situs tersebut. Meski merupakan objek pelestarian dari BPCB DIY, PT Taman menerima $100 \%$ pendapatan pariwisata dari kedua situs tersebut tanpa disalurkan ke kas umum negara.

Penggunaan situs Candi Prambanan dan Ratu Boko dalam bidang pariwisata oleh PT Taman dapat dikategorikan sebagai penggunaan Barang Milik Negara berstatus dioperasikan pihak lain sesuai penugasan pelayanan umum oleh Kementerian Pendidikan dan Kebudayaan; dan Kementerian Pariwisata dan Ekonomi Kreatif. Menurut Peraturan Menteri Keuangan (PMK) Nomor 76/PMK.06/2019 perubahan atas PMK Nomor 246/PMK.06/2014 tentang Tata Cara Pelaksanaan Penggunaan Barang Milik Negara Pasal 18 Ayat 5, mengatur keuntungan atas pendapatan setelah dikurangi beban operasional disetorkan ke kas umum negara, kecuali ditentukan peraturan perundangundangan. Peraturan perundang-undangan yang dapat mendukung tidak disetornya keuntungan PT Taman adalah Peraturan Pemerintah Nomor 45 Tahun 2005 Pasal 65 Ayat 3 yang mengatur bahwa pemerintah memberikan kompensasi termasuk margin yang diharapkan ketika penugasan yang diberikan tidak menguntungkan secara finansial. Kompensasi tersebut dapat berupa seluruh keuntungan yang didapat.

4.2.3. Penggunaan Biaya Perawatan Cagar Budaya yang Tidak Berstatus Barang Milik Negara

Dalam melestarikan cagar budaya, BPCB DIY tidak hanya melestarikan cagar budaya yang dimiliki atau dikuasai oleh pemerintah, melainkan juga melestarikan cagar budaya yang dimiliki atau dikuasai perorangan atau badan hukum lainnya. Kegiatan pelestarian, termasuk kegiatan pemeliharaan yang dilakukan menggunakan beban APBN yang dianggarkan oleh BPCB DIY.

Hal tersebut tidak menimbulkan masalah ketika cagar budaya yang dipelihara merupakan cagar budaya yang dimiliki atau dikuasai oleh pemerintah. Masalah timbul ketika cagar budaya dalam pelestarian BPCB DIY merupakan milik atau dalam penguasaan perorangan atau badan hukum lain. Di wilayah kerja BPCB DIY, kasus tersebut terjadi pada cagar budaya milik Keraton Yogyakarta dan cagar budaya yang sedang dioperasikan PT Taman.

Pada kasus Keraton Yogyakarta, BPCB DIY membebankan APBN untuk pemeliharaan cagar budaya yang dimiliki oleh Keraton Yogyakarta, seperti Situs Plengkung Gading dan Tamansari. Sedangkan pada kasus PT Taman, pemeliharaan Situs Candi Prambanan dan Ratu Boko masih dibebankan pada anggaran BPCB DIY. Kasus PT Taman bertentangan dengan PMK No. 76/PMK.06/2019 tentang Perubahan Kedua Atas PMK Nomor 246/PMK.06/2014 [HP1] yang menyatakan bahwa biaya pemeliharaan BMN selama jangka waktu penggunaan BMN untuk dioperasikan oleh pihak lain dibebankan kepada pihak lain yang mengoperasikan BMN."

Sebagai perbandingan pengoperasian BMN oleh pihak lain, khususnya BUMN, dapat dilihat pada PT Angkasa Pura II sebagai pengelola BMN yakni Bandara Soekarno-Hatta dan Halim Perndanakusuma. PT Angkasa Pura II merupakan BUMN yang bergerak di bidang pengelolaan bandara Indonesia, bersama dengan PT Angkasa Pura I. Seperti PT Taman, 100\% saham PT Angkasa Pura II dimiliki oleh pemerintah. Bandara Soekarno-Hatta yang menjadi objek pengelolaan perusahaan tersebut merupakan BMN jika dilihat dari sejarah pengadaannya. Bandara SoekarnoHatta diadakan melalui multiproyek yang diadakan oleh pemerintah. Proyek pertama pada tahun 1974-1975, berupa pembangunan tiga landasan pacu, jalan aspal, tiga bangunan terminal internasional, tiga bangunan terminal domestik, dan satu terminal haji, dilakukan melalui tender dan dimenangkan oleh konsorsium konsultan asal Kanada yang terdiri dari Aviation Planning Services Ltd., ACRESS International Ltd., dan Searlee Wilbee Rowland (SWR).

Pada laporan keuangan PT Angkasa Pura II tahun 2019, disebutkan bahwa kegiatan pemeliharaan atas beban perusahaan merupakan pemeliharaan atas kantor perusahaan dan bandara yang menjadi objek pengelolaan. Pemeliharaan yang dilakukan berupa pemeliharaan infrastruktur bandara, pemeliharaan fasilitas publik, pemeliharaan alat besar, pemeliharaan fasilitas kargo, dan sebagainya. Pemeliharaanpemeliharaan tersebut memang tidak disebutkan secara tersurat pada beban akrual, namun tersebar dalam tugas dan fungsi divisi-divisi yang memiliki tugas dan fungsi pemeliharaan.

Perbandingan kedua dapat dilihat di Pusat Pengelolaan Komplek Gelora Bung Karno Jakarta (PPKGBK) yang merupakan Badan Layanan Umum (BLU) di bawah Sekretariat Negara yang bertugas mengelola Komplek Gelanggang Olahraga (Gelora) Bung Karno, atau biasa disebut GBK. GBK memiliki status cagar 
ANALISIS PENGELOLAAN BENDA CAGAR BUDAYA SEBAGAI KEKAYAAN DIKUASAI NEGARA DI BALAI PELESTARIAN CAGAR BUDAYA D.I

YOGYAKARTA.

Muhammad Naufal Faraj El Gibarj ${ }^{1}$ dan Pratin $^{2}$

budaya dengan nomor registrasi CB. 1085 dengan pemeringkatan SK Gubernur DKI Jakarta berjenis Situs Cagar Budaya.

Peraturan Pemerintah Republik Indonesia Nomor 74 Tahun 2012 tentang Perubahan atas Peraturan Pemerintah Nomor 23 Tahun 2005 tentang Pengelolaan Keuangan Badan Layanan Umum, menyatakan bahwa Pendapatan dapat dikelola langsung untuk membiayai belanja BLU sesuai RBA. Belanja yang dimaksud terdiri dari berbagai unsur biaya, termasuk biaya pemeliharaan. Hal tersebut sejalan dengan operasional keuangan PPKGBK yang menggunakan pendapatannya untuk pemeliharaan, seperti dalam pernyataan artikel ANTARANEWS.com (2018), menyatakan bahwa biaya operasional stadion GBK sebulan adalah Rp1 miliar, dan untuk biaya pemeliharaan kolam sebesar Rp700 juta sebulan, menggunakan subsidi silang dari dana Pusat Pengelolaan Komplek Gelora Bung Karno. [HP2]

Sedangkan pada PT Taman, biaya pemeliharaan yang dianggarkan tidak mencakup pemeliharaan Situs Candi Prambanan dan Ratu Boko. Dalam laporan keuangan PT Taman tahun 2019, disebutkan bahwa kegiatan pemeliharaan yang dilakukan berupa pemeliharaan bangunan kantor dan fasilitas di lingkungan situs, seperti lahan parkir, taman, dan gudang.

\subsection{Alternatif Penyelesaian Masalah}

Beberapa alternatif penyelesaian atas masalah-masalah yang teridentifikasi oleh peneliti antara lain:

\subsubsection{Melakukan Koordinasi dengan Kementerian Keuangan Tentang Cagar Budaya yang Menjadi Objek Pelestarian BPCB DIY Sebagai Barang Milik Negara}

Atas masalah status cagar budaya yang tidak diberlakukan dengan mekanisme BMN, dapat diperkukuh statusnya dengan koordinasi dengan Kementerian Keuangan, khususnya Direktorat Jenderal Kekayaan Negara. Penguatan status cagar budaya sebagai BMN akan memperjelas mekanisme yang digunakan, termasuk penatausahaan dan pemeliharaan.

\subsubsection{Meningkatkan Tertib Administrasi Cagar Budaya Sebagai Barang Milik Negara \\ Cagar budaya yang telah jelas statusnya} sebagai BMN akan lebih baik jika administrasinya tertib, khususnya pada sistem informasi, yakni SIMAK BMN dan SIMAN BMN. Penertiban administrasi berupa pelengkapan data melalui kegiatan penatausahaan. Jika SDM yang ada kurang memadai, dapat dilakukan pelatihan tentang sistem informasi terkait.

\subsubsection{Mengkaji Kembali Penggunaan Beban Pemeliharaan atas Cagar Budaya yang Tidak Dimiliki atau Dikuasai Pemerintah}

Atas kasus BMN cagar budaya yang tidak dimiliki atau dikuasai pemerintah agar dilakukan pengkajian atas pengenaan beban pemeliharaan pada APBN. Jika pemeliharaan yang dimaksud adalah pemeliharaan atas BMN yang digunakan untuk saranaprasarana perorangan atau badan hukum selain pemerintah, maka hal tersebut tidak sesuai peraturan perundang-undangan tentang Barang Milik Negara yang berlaku tentang pemeliharaan BMN. Jika pemeliharaan yang dimaksud adalah pemenuhan kewajiban BPCB sebagai pelestari cagar budaya, maka hal tersebut dapat dibenarkan. Kedua hal tersebut perlu dipertegas dalam kajian agar tidak terjadi miskonsepsi antara pemeliharaan BMN dan pemeliharaan cagar budaya.

\section{KESIMPULAN DAN SARAN}

\subsection{Kesimpulan}

Benda Cagar Budaya, atau cagar budaya secara umum, merupakan Barang Milik Negara dalam kategori Kekayaan Negara Lain-Lain. BPCB merupakan UPT Kementerian Pendidikan dan Kebudayaan yang bergerak di bidang pelestarian cagar budaya dan bertanggung jawab kepada Direktur Jenderal Kebudayaan. BPCB DIY merupakan BPCB dengan wilayah kerja Daerah Istimewa Yogyakarta.

BPCB DIY telah melakukan pengelolaan secara baik dalam segi cagar budaya, sedangkan dalam segi cagar budaya sebagai BMN masih terdapat beberapa masalah, antara lain penatausahaan cagar budaya sebagai BMN belum maksimal, pendapatan PT Taman atas Candi Prambanan dan Ratu Boko tidak disetorkan ke Kas Umum Negara, dan beban pemeliharaan APBN cagar budaya pada cagar budaya yang tidak dimiliki atau dikuasai pemerintah.

\subsection{Saran}

Seperti yang telah disebutkan dalam alternatif penyelesaian masalah, saran yang dapat diberikan peneliti kepada BPCB DIY, kementrian yang mengurusi kebudayaan, dan Kementrian Keuangan adalah:

a. Melakukan koordinasi dalam pengelolaan cagar budaya sebagai Barang Milik Negara.

b. Meningkatkan tertib administrasi Cagar Budaya sebagai Barang Milik Negara.

c. Mengkaji kembali penggunaan beban pemeliharaan atas cagar budaya yang tidak dimiliki atau dikuasai pemerintah

\section{IMPLIKASI DAN KETERBATASAN}

Hasil penelitian diatas menunjukkan bahwa cagar budaya adalalah BMN yang unik atau spesifik,

Halaman 39 
ANALISIS PENGELOLAAN BENDA CAGAR BUDAYA SEBAGAI KEKAYAAN DIKUASAI NEGARA DI BALAI PELESTARIAN CAGAR BUDAYA D.I

YOGYAKARTA

Muhammad Naufal Faraj El Gibarj ${ }^{1}$ dan Pratin $^{2}$

sangat berbeda karakteristiknya dengan BMN atau aset tetap pada umumnya. Pertanyaannya adalah apakah peraturan pengelolaan BMN yang bersifat umum dapat diterapkan secara efektif pada pengelolaan BMN yang bersifat khusus/unik dalam hal ini cagar budaya. Apa perlu dikaji/dibuat peraturan khusus pengelolaan BMN yang bersifat unik/khusus seperti BMN berupa cagar budaya.

Penelitian ini sangat terbatas pemanfaatannya khususnya dalam hal akan dipakai sebagai bahan pengambilan kebijakan,mengingat penelitian ini adalah karya tulis mahasiswa tingkat III (bukan skripsi) dan pengumpulan data dilakukan di masa pandemi covid19 , sehingga diperlukan penelitian lanjutan yang lebih mendalam atas tema ini.

\section{DAFTAR PUSTAKA}

\section{Buku dan atau Sumber Lainnya}

Global Partnership Innovation: PT Angkasa Pura II (Persero) Laporan Tahunan 2019, https://www.angkasapura2.co.id/

Laporan Manajemen Perusahaan Tahun 2019 (Audited) PT Taman Wisata Candi Borobudur, Prambanan \& Ratu Boko (Persero),

http://corporate.borobudurpark.com/lapo ran-tahunan-2019/

Aditya Eko Sigit Wicaksono, (2018), Mengintip Perawatan Kolam Studio Akuatik Gelora Bung Karno., ANTARANEWS.com, https://www.antaranews.com/

Ahyar Juni (2018), Penuntun Membuat Skripsi dan Menghadapi Presentasi Tanpa Stres, https://repository.unimal.ac.id

Balai Pelestarian Cagar Budaya Derah Istimewa Yogyakarta, tentang kami, http://kebudayaan.kemdikbud.go.id/bpcb yogyakarta/tentang-kami/

\section{Peraturan}

Peraturan Menteri Keuangan Nomor 234/PMK.01/2015 tentang Organisasi dan Tata Kerja Kementerian Keuangan, https://jdih.kemenkeu.go.id/

Peraturan Menteri Keuangan Nomor 246/PMK.06/2014 tentang Tata Cara Penggunaan Barang Milik Negara, https://jdih.kemenkeu.go.id/

Peraturan Menteri Pendidikan dan Kebudayaan Nomor 30 Tahun 2015 tentang Organisasi dan Tata Kerja Balai Pelestarian Cagar Budaya, https://jdih.kemdikbud.go.id/

Peraturan Pemerintah Nomor 23 Tahun 2005 tentang Pengelolaan Keuangan Badan
Layanan

Umum, https://peraturan.bpk.go.id/

Peraturan Pemerintah Nomor 27 Tahun 2014 tengan Pengelolaan Barang Milik Negara/Daerah, https://www.hukumonline.com/pusatdata L

Permanawiyat Widhi, Sambodo Noorman, Mas'ad. Anindyatri Annisa, (2020), Statistik Kebudayaan 2020, http://publikasi.data.kemdikbud.go.id/

Undang-Undang Dasar Negara Republik Indonesia Tahun 1945 ,

http://www.dpr.go.id/jdih/uu1945

Undang-Undang Republik Indonesia Nomor 11 Tahun 2010 tentang Cagar Budaya, https://www.hukumonline.com/pusatdata L 